\title{
ПРОФЕСИОНАЛИЗАЦИЈА НА БЕЗБЕДНОСНИОТ СЕКТОР НА РЕПУБЛИКА МАКЕДОНИЈА - ДИЛЕМИ И ПРЕДИЗВИЦИ
}

\section{Кратка содржина}

Професионализачијата и професионализмот се засноваат на системски теориски основи и се смета дека се повеке од потребни затоа што се во функиија да го обезбедат потребниот квалитет во работењето. Основниот концепт во овој труд се базира на професионализмот и на професијата што создава и негува посебна спечијална култура, која се стекнува со процесот на сочијализација. Оттука, теоретската експликачија на трудот е насочена најнапред кон разгледување на концептот на професионализачија, а потоа кон согледување на професионализмот и професијата во однос на тоа како клиентите на одредена професија ја прифаќаат надлежноста и авторитетот на таа професија.

Клучни зборови: ПРОФЕСИОНАЛИЗАЦИЈА, ПРОФЕСИОНАЛИЗАМ, ПРОФЕСИЈА, БЕЗБЕДНОСЕН СЕКТОР, СПЕЦИЈАЛИЗАЦИЈА

\section{Вовед}

Во основа денес сме сведоци на ограничени дискусии за професионализацијата, односно дискусиите за ваквите прашања се сведуваат на минимум, што секако дека е неоправдано. Одредени дискусии може да ги оцениме дека се во рамките на класичниот пристап кој ги дава основните елементи за безбедносната ориентација, што значи дека тие ја гледаат професионализацијата низ призмата на когнитивните сознанија кои, пак, во основа, имплицираат знаење за безбедноста, за безбедносниот сектор итн. Други размислувања се во насока на давање одредени размислувања и судови за сензитивноста во работата врзана со безбедносните прашања, додека, пак, трети особено место им даваат на интеракцијата и меѓузависноста на односите кои, главно, вклучуваат и комбинации на вредности, стандарди и критериуми. Сите размислувања не ја намалуваат научната вредност на овој концепт, но, во основа, мора да се направат и дополнителни напори за да се надомести инсуфициентноста во актуелната состојба.

Во рамките на нашите размислувања особено е важно прашањето за самиот пристап кон овој проблем кој имплицира сложен процес внатре во самата држава, како и прашањето за вкупната безбедносна култура, која има бројни димензии почнувајќи од заедничките интереси, заедничките вредности, политичкобезбедносните процеси, сложениот однос во безбедносната заедница, но и од околностите во кои човекот живее и работи. Единствената важна интерпретација на општествената природа на човекот е онаа која човекот го вбројува во општествената целост и како дел од таа целост тој ги остварува своите интерси, а исто та- 
ка и живее во една уредена демократско-безбедносна средина во која има изградена хиерархиска структура и се бара апсолутна покорност од своите делови кои заедно го сочинуваат идиличното богатство на заемната помош на совршената власт. Значи, тука споменатите амбиваленции неминовно се одразуваат и на самите поединци кои се ангажираат за извршување одредени безбедносни задачи со што се влијае на оформување на нивниот пристап и самата имплементација на стандардите во безбедносната пракса. Оттука, само општествено активен однос спрема оваа проблематика ќе придонесе кон афирмација и развој на основните постулати во кои професионализацијата ќе доведе до акумулација на безбедносно-културниот капитал од индивидуата до самото општество.

\section{1. Општо за професионализацијата}

Во основа, во ниту една современа расправа за безбедноста, одбраната, здравството, администрацијата итн. не ја заобиколува темата за професионализација, затоа што таа е сеприсутен фонемен кој се појавува во секој сегмент од општеството. Решавањето на ова прашање е голема грижа не само за институциите, органите и организациите, бизнис-заедницата, туку и за јавната безбедност и, воопшто, за државта. Оттука, не е сеедно какви чекори се преземаат на овој план и особено не е сеедно како се одговара на прашањето како до поголема професионализација на субјектите во кои доминира безбедносната компонента, како природен елемент на безбедносната структура.

Од аспект на остварување на безбедноста, нема дилема дека субјектите задолжени за безбедност мора да имаат доволно моќ и авторитет за да ја вршат својата работа, но не во толкава мера за да ја загрозат благосостојбата на општеството или на поединецот. Оттука, нормалниот одговор на оваа дилема потенцира три аспирации: легитимност, професионализам и одговорност. Така, главните цели се насочени кон постојана легитимност, постојан професионализам и постојана одговорност. Сите три услови мора да постојат и да бидат исполнети за да говориме дека постои демократско управување. Професионалното однесување и одговорноста ја поткрепуваат легитимноста, додека одговорноста ја овозможува професионалноста, а легитимноста го овозможува потребниот степен на професионална самостојност (Бакрески, О., 2012).

Значи, професионализмот е категоријална црта што се однесува на одредени вредности, вештини, ориентација и управување. Принципите на фер однесување, интегритет, грижа за човековите права, одговорност и минимална употреба на сила се основните елементи во секој концепт на демократското управување. Професионализмот не смее да се вмеша во дискриминаторно, корумпирано или насилно искористување на својата моќ. Самостојноста (ограниченоста) што ја има безбедносниот сектор се базира врз довербата на општеството дека овој сектор ќе прифати дел од вредностите што ќ ја условуваат демократската рамнотежа на етичко и на професионално водење (Fluri P., Hadžić M. (eds.), 2004). Излегувањето од прегратките на професионализмот ќе резултира со грубо, корумпирано и некомпетитивно однесување, а во некои случаи може да доведе дури и до јавни 
скандали, што ја наметнува потребата од сериозна регулатива во овој сектор (Born H. Caparini M. and Cole E., 2007).

Оттука, за да не дојде до тоа е потребно да преовладува совеста. Совеста има клучно значење за иднината на човекот, а со тоа се придонесува граѓаните со своето однесување и ангажман да дадат голема поддршка на односите кои треба да се доживуваат од поинаков аспект, бидејќи ги осознаваат во својата законитост. Во основа, професијата може да се изгради со многу активности, почнувајќи од образованието, однесувањето, претставувањето итн. Покрај професионализмот, свое значење има и одговорноста, која, генерално, значи проактивен пристап за себе, заштита на себе од другите, одговорност кон државата, кон вредностите итн. Професионализмот значи и партиципативно учество и придонес, но и идеја како да се поттикне иновативноста и креативноста, што во основа ќ значи иновативност, решителност, како и преземање акција за да се овозможат промени во безбедносна смисла на зборот.

2. Терминолошки дивергенции околу поимот и употребата на професионализацијата и професионализмот

Професионализацијата е процес со кој некое организирано занимање што располага со посебни, езотерични способности и кое води сметка за квалитетот на сопствената работа, и со својот придонес кон општествената благосостојба - обезбедува ексклузивно право на изведување посебни видови работа и контрола на правото на одредување и на вреднување на начинот на вршење на работата (E. Freidson, 1994) или професионализацијата е процес низ кој одредени професии развиваат заеднички обрасци на образование, однесување, работа и (професионален) надзор (A. Abbott, 1988).

За разлика од професионализацијата, професионализмот е истовремено индивидуална карактеристика и идеолошка позиција. Поточно, идејата дека припаѓањето на една професија со себе носи збир од стандардизирани квалитети и вредности кои се рефлектираат во начинот на кој се извршува работата, како и правните и етичките стандарди кон кои се придржува (Weckert, J., Lucas, R. 2013). Cо други зборови, нивото на способност или перфекција која се очекува од професионалецот се дефинира како професионализам. Џон Култген во својата книга „Етика и професионализам“ (Kultgen: 2012 Ethics and Professionalism) наведува дека професионализмот подразбира етика и моралност во својата работа и дејност.

Интересна е аргументацијата на Давид Меистер, кој потенцира дека професионализмот е во директна корелација и со продуктивноста и со производството. Тој означува стремеж кон совршенство, а не само компетитивност. Во овој контекст, изведбата, целите и квалитетите кои ја карактеризираат и симболизираат професијата или професионалната личност може да бидат дефинирани како професионализам.

Во основа, професионализмот, а особено професионалната компетитивност е вообичаена и разумна употреба на комуникација, знаење, технички вештини, расудување, емоции, вредности и рефлексија во секојдневната практика во ко- 
рист на поединецот и заедницата на која ѝ се служи (Spandorfer, J. 2010). Оттука, професионализмот е во функција на заштитата на имиџот на професијата која се врши, а исто така подразбира исполнување одредени критериуми, став и однос (Bruce, K., Ahmed, A., D. 2014).

Професионализмот дефинира три карактеристики, и тоа: експертиза, одговорност и корпоративност. ${ }^{1}$ Во оваа насока, во Оксфордскиот речник, при дефинирањето на професионализмот, се земаат предвид овие аспекти: експертиза и специјализирани вештини, мотивација (со финансиска компензација), познавање на теоретско знаење како и поврзаност со одредени работни прашања (социјален статус). Алтруизмот, отчетноста, интегритетот, службата, почитта и честа, исто така, спаѓаат во карактеристиките на професионализмот. Концептот и теориската основа за професионализам при извршување на работата се имплементираат уште во периодот на едукација и оспособување (Wear, D, Bickel, J. 2000).

Професионализмот често се дефинира и како строго придржување кон одговорност, чесност и љубезност при работата со физички и правни лица. Оваа особина подразбира високо ниво на ефективност и ефикасност која ги надминува основните потребни услови.

Генерално, професионализмот се постигнува преку организирање група дисциплинирани поединци кои се придржуваат до одредени етички стандарди, кои себеси се перципираат и се доживуваат од страна на другите како носители на специфично знаење и вештини, преку признаен начин на изучување, кој вклучува истражување, обука и тренинг на високо ниво, и кои се оспособени да ги применат овие вештини и знаења во интерес на другите.

Професионализмот може да биде претставен на два начина - првенствено како компетенции и очекувани вештини, а секундарно тој се однесува на вршење одредена работа од страна на професионални лица, а не од страна на аматери (Ravand, М. 2014).

\section{3. Како да се дојде до поголема професионализација}

Професионализацијата е динамична категорија која е условена од бројни фактори и е во тесна корелација со развојот на општеството. Во основа, таа се остварува во подолг временски период и е условена од демократскиот амбиент во државата и од односните меѓу самите субјекти во државата, почнувајќ од семејството, училиштата, верските заедници, безбедносните институции, итн.

Значи, согледувањето на проблемот на професионализацијата единствено е можен само преку детално познавање на сложените, испреплетени внатрешни односи, како и преку разгледување на клучните елементи кои ја имаат централната улога во креирањето соодветен амбиент за работа, почнувајќки од средината, достигнатото ниво на образование, нивото на свеста, динамичноста и сложеноста на односите во сферата на безбедноста, општествениот развој, повеќеструктурните форми на комуникација итн.

\footnotetext{
${ }^{1}$ Military Professionalism in Asia: Conceptual and Empirical Perspectives. East West Center. 2001.
} 
Оттука, основното прашање кое се поставува не е дали е потребна професионализација, туку - како да се дојде до поголема професионализација? За да може да се дојде до поголема професионализација, потребно е да се исполнат неколку услови.

Првиот услов е поставувањето минимум стандарди, а тоа придонесува кон развој на професионализацијата во овој сектор. Професионалните знаења се основниот столб кој ги одредува почетоците, целите и развојот на процесот на професионализација.

Вториот услов е да се подигнат стандардите при вработување за да се бара стучност и компетентност како минимум стандарди. Професионалните компетенции и доаѓаето до нив е условено од практично извршување на задачите, а тука до израз доаѓа стекнатото знаење. Ова значи, прво, да се стремат безбедносните субјекти за адекватно кадровско планирање и да се избираат најдобрите кандидати поради специфичноста на дејноста и професијата и, второ, овој концепт треба да опфаќа стручни профили кои треба да подлежат на континуирано стручно усовршување, нивна соодветна подготовка за разбирањето на секојдневните работи и работење итн. Вокација за која е потребно специјализирано знаење, за кое често е потребна долготрајна и интензивна подготовка, која вклучува учење, вештини и методи, како и научни, историски или теориски начела на кои почиваат наведените вештини и методи. Тоа специјализирано знаење се одржува преку моќта на организацијата или со усогласување на ставовите за високите стандарди за реализација и однесување, како и со согласност од членовите на професијата на постојано истражување и таков вид работа, чија примарна цел е вршење јавна служба (Merriam Webster (ed.), Webster's Third New International Dictionary, Unabridged. 2000 Springfield, MA: Merriam-Webster).

Третиот услов е целосна поделба на работите. Со професионализацијата се остварува целосна поделба на работите. Зајакнувањето на критериумите за внатрешната организација и систематизација на работните места не треба да се однесува само на раководните структури, туку и на потчинетите слоеви.

Четвртиот услов е образованието. Образованието е клучен фактор и заедно со обуките и усовршувањата ќе придонесе за поголема професионализација и развој на безбедносната дејност. Знаењето што се добива од образовниот процес е главна детерминанта во развојот затоа што се темели на совладување и стекнување комплексен корпус од компетенции, способности и вештини. Тоа е вокација во која знаењето или праксата се користат за давање услуги на други. Нејзините членови ја искажуваат својата приврзаност преку експертиза, интегритет, моралност, алтруизам и промоција на јавното добро во сопствениот домен на работа. Таа приврзаност ја обликува основата за општествениот договор помеѓ професиите и општествата, што за возврат осигурува професионална автономија во практиката и привилегија на саморегулација. Професиите и нејзините членови имаат одговорност кон општеството и кон оние на кои им даваат услуги (Oxford English Dictionary, 1989 Oxford: Clarendon Press).

Петтиот услов е обезбедување политичка неутралност. Вработените во 
безбедносниот сектор треба да бидат аполитични, што значи дека тие ќе бидат посветени на работата и на професионалното извршување на задачите. Во основа, професионализацијата ќе овозможи извршување на задачите врз основа на законот, а не врз основа на нечии желби. Тоа е еден вид гаранщија дека вработените професионално ќе ги извршуваат своите задачи и дека целосно ќе бидат посветени на нивно спроведување, што ќе значи висок степен на одговорност, а тоа е, впрочем, еден од елементите што го бара и нивната професија.

Шестиот услов е оценување на работата и работењето. Сѐ што се работи мора да подлежи на оценување. Овој елемент може да се спроведе преку јакнење на постојаните мерки за проверки на знаењата.

Седмиот услов е одговорноста која оди рака под рака со професионализацијата. Одговорноста подразбира да се објасни некое однесување и да се биде отворен кон туѓата критика. Одговорноста бара обврските, овластувањата и функциите на одговорните тела да бидат така дефинирани што работата на потчинетите да може успешно да се надгледува и оценува. Одговорноста како категорија се врзува за извршување на задачите во предвиденото време и во согласност со пропишаните стандарди. Ова води кон професионална организација која дејствува превентивно сѐ со цел да се спречува извршување на криминални дела. Исто така, одговорноста значи дека полицијата нема да се раководи само на своите претпоставки за ефикасно и рационално функционирање, туку ќе го земе предвид и сето тоа што го очекува заедницата од неа (Бакрески, О. 2012). 


\section{Литература}

Бакрески, О., (2012): Контрола на безбедносниот сектор, Филозофски факултет, Скопје.

Bruce, K., Ahmed, A., D. (2014): Conceptions of Professionalism: Meaningful Standards in Financial Planning. Gower Publishing Company, British Library.

Denhart, R., Denhart, J., New Public Service: Serving Rather Than Steering, Public Administration Review, 60

Evropska komisija, SIGMA, OECD, Principi javne uprave, 2014.

Kuperus, H., Rode, A., Top Public Managers in Europe: Management and Working Conditions of the Senior Civil Servants in the European Union Member States (Study Commissioned by the French EU-Presidency), European Institute of Public Administration, Maastricht, 2008.

Maccarthaigh, M, Boyle R., Civil Service Accountability: Challenge and Change, State of the Public Service Series, Research paper No. 12, 2014.

Military Professionalism in Asia: Conceptual and Empirical Perspectives. East West Center. 2001.

Profesionalizacija rukovodnog kadra u Crnoj Gori: Između države i politike, Podgorica, 2014

Ravand, M. (2014): Human Resource Professionalism: A Panacea for Public Organizations. Author House, Bloomingdale.

Spandorfer, J. (2010): Professionalism in Medicine. Cambridge: Cambridge University Press

Wear, D, Bickel, J. (2000): Educating for Professionalism: Creating a Culture of Humanism in Medical Education, Iowa City: University of Iowa Press

Weckert, J., Lucas, R. (2013): Professionalism in the Information and the Communication Technology Industry. Australian National University, E Press, 
Oliver BAKRESKI

\section{PRFOESSIONALIZATION OF THE SECURITY SECTOR IN THE REPUBLIC OF MACEDONIA - DILLEMMAS AND CHALLENGES}

\section{Summary}

Professionalization and professionalism are based on systematic theoretical pillars and considered as more than necessary because their function is to provide the necessary work quality.

The primary concept in this paper is aimed at professionalism and profession which creates and nourishes a distinctive, special culture, acquired with the socialization process.

Hence, the theoretic explication of the paper is focused in the first place toward the scope of the professionalization concept, and subsequently toward perceiving the professionalism and profession, the competence and authority, accepted by the clients of a certain profession.

Keywords: PROFESSIONALIZATION, PROFESSIONALISM, PROFESSION, SECURITY SECTOR, SPECIALIZATION. 